\title{
Identifying the management barriers for establishing suggestions system: A case study of educational system
}

\author{
Masoud Nouri* and Mohammad Ahanchi
}

Department of Humanities, Sanandaj Science and Research Branch, Islamic Azad University, Sanandaj, Iran

\begin{tabular}{|c|c|}
\hline A R T I C L E I N F O & A B S T R A C T \\
\hline $\begin{array}{l}\text { Article history: } \\
\text { Received April 28, } 2012 \\
\text { Received in Revised form } \\
\text { July, 29, } 2012 \\
\text { Accepted } 10 \text { August } 2012 \\
\text { Available online } \\
\text { 17 August } 2012 \\
\text { Keywords: } \\
\text { Cooperation } \\
\text { Suggestion } \\
\text { Suggestions system }\end{array}$ & $\begin{array}{l}\text { Suggestions system is one of the new cooperative management plans, which affects making } \\
\text { good decisions, self-confidence and employees occupational approval. The aim of this research } \\
\text { is to survey the barriers for establishment of suggestion system. The proposed study designs } \\
\text { and distributes a questionnaire among } 195 \text { out of } 26550 \text { managers who work for educational } \\
\text { system in city of Kermanshah, Iran. The primary purpose of this survey is to learn whether lack } \\
\text { of accepting any risk on behalf of management team, conflict of interest in management style, } \\
\text { lack of belief on suggestions system in an organization are important barriers of executing } \\
\text { suggestions system in an organization or not. The results of Freedman test confirm all seven } \\
\text { components of the hypothesis. As a result, lack of accepting risk among management team is } \\
\text { number one barrier in having suggestion system followed by existing conflict between } \\
\text { management style and suggestions system and lack of management's belief to suggestions } \\
\text { system, weakness in education for suggestions system and fear in management disruption } \\
\text { because of having suggestions system. The other barriers coming in the last priority in terms of } \\
\text { their relative importance include lack of management's support to suggestions system and } \\
\text { weakness in management position because of accepting suggestions system. }\end{array}$ \\
\hline
\end{tabular}

(c) 2012 Growing Science Ltd. All rights reserved.

\section{Introduction}

Suggestion system plays an important role on increasing management capabilities on learning through feedback received and improving the entire system. An effective suggestion system could easily unveal any existing shortcomings in the system and helps management team find better solutions to overcome troubles. Despite the advantages, many manegers avoid of executing such systems for different reasons such as fear in management disruption becuase of having suggestions system, weakness in education for estabilishin suggestions system, etc. During the past few decades, there have been tremendous efforts to find out why people cannot have efficient suggestion system (Milner et al. 1995; Recht \& Wilderom, 1998; Heresy \& Blanchard, 2001; Anderson, 2004).

\footnotetext{
* Corresponding author. Tel: +989183364121

E-mail addresses: m_nouri_sts@yahoo.com (M. Nouri) 
Yi et al. (2011) discussed that despite increasing awareness of the importance of customer behaviors in service delivery, there has been little attention on understanding consequences associated with employees. They investigated the impacts of customer participation and citizenship behavior on employee performance, satisfaction and commitment, as well as indirect impacts on turnover intention. They also examined how similarity and likeability moderated the impacts of customer participation and citizenship behavior on employee satisfaction. Their study also included a laboratory experiment and provided some support for causal direction.

Pirayesh et al. (2012) presented an empirical study to measure the impact of information technology, hiring high quality skilled management team, using high quality standards and increasing employees' awareness on managing internal control. The survey used a questionnaire based on Likert scale and distributes among the people who work in either administration or financial sectors of governmental agencies in province of Zanjan, Iran. The results of the study indicated that the implementation of information technology positively influences management team to control their system, more effectively, using more skilled and specialized managers positively influences management internal control, an organization with suitable standard positively influences management internal control and increasing employees' awareness positively influences management internal control.

Jun et al. (2006) studied the transferability of total quality management (TQM) practices to offshore manufacturing enterprises by validating relationships among top management commitment, human resource (HR)-focused TQM practices, employee satisfaction, and loyalty. The research objective was to isolate critical TQM practices, which would enhance employee satisfaction and loyalty among maquiladora workers. The results indicated that employee empowerment, teamwork, and employee compensation had an important and positive impact on employee satisfaction. Gao et al. (2011) investigated the role of leader trust and employee voice using the moderating impact of empowering leader behaviors.

Ahangari and Amirzadeh (2011) implemented a database of 360 corrective feedback moves where two EFL teachers provided to their learners at three levels of proficiency. Eight types of corrective feedback were determined and their distribution in relation to proficiency levels of learners was detected. The results indicated that recast was the most frequently implemented type of corrective feedback by the teachers at all three levels of proficiency. Atwater and Brett (2005) studied the factors, which impact leaders' reactions to $360^{\circ}$ feedback and the relationship of feedback reactions to subsequent development activities and changes in leader behavior. According to Atwater and Brett (2005), for leaders with relatively low ratings, the people who agreed with others about their ratings were less motivated than the people who received low ratings and over rated themselves. In addition, for leaders with high ratings, agreement between self and other did not impact their motivation.

Atwater and Brett (2005) studied the factors, which impact leaders' reactions to $360^{\circ}$ feedback and the relationship of feedback reactions to subsequent development activities and changes in leader behavior. According to Atwater and Brett (2005), for leaders with relatively low ratings, the people who agreed with others about their ratings were less motivated than the people who received low ratings and over rated themselves. In addition, for leaders with high ratings, agreement between self and other did not impact their motivation.

Vakil Alroaia and Najafi (2012) presented a 360 ${ }^{\circ}$ feedback system for performance measurement of all employees who work for municipality of the city of Tabas located in east part of Iran. The proposed model of this paper also used hierarchical method to cluster different attributes based on various characteristics and implements analytical hierarchy process to find the relative importance of all items. The survey used five personal characteristics including cognitive, technical, personal and human skills and for each major item, the proposed model considers various sub-criteria. The results indicated that technical and cognitive skills were the most important personal characteristics followed 
by human and personal characteristics. The results of this survey showed that responsibility and quality of work are the most important employee characteristics.

Wood et al. (2004) examned the feasibility of a 360-degree evaluation to measure radiology resident competence in professionalism and interpersonal/communication skills. They used an evaluation form with 10 Likert-type items associated with professionalism and interpersonal/communication skills was completed by a resident, supervising radiologist and patient after resident-patient interactions associated with breast biopsy procedures. Residents were also evaluated by faculty, using an end-ofrotation global rating form. Fifty-six completed 360-degree data sets and seven rotational evaluations for seven residents were investigated and compared. The results of this pilot study recommended that self, faculty, and patient evaluations of resident performance constituted a reliable evaluation of resident competence. However, they reported that additional data were necessary to determine whether the 360-degree assessment could be incorporated into residency programs and how frequently the assessment could be performed.

In this paper, we present an empirical survey among people who are working in educational system in province of Kermanshah, Iran. The purpose of this study is to learn more about the barriers on having suggestion system in educational environment. The study examines the effects of seven factors as barriers on having efficient suggestion systems. The organization of this paper first present details of survey in section 2, section 3 presents the ranking system and concluding remarks are given in the last to summarize the contribution of the paper.

\section{The proposed study}

The proposed study of this paper considers one main hypothesis along with seven sub-hypotheses.

\subsection{Main hypothesis}

Lack of accepting any risk on behalf of management team, conflict of interest in management style, lack of belief on suggestions system in an organization are important barriers of executing suggestions system in an organization. The proposed study of this paper uses a standard questionnaire and plan to distribute it among a randomly selected population from 26550 people who work for educational services in city of Kermanshah, Iran. The sample size is calculated as follows,

$$
n=\frac{N \times z_{\alpha / 2}^{2} \times p \times q}{\varepsilon^{2} \times(N-1)+z_{\alpha / 2}^{2} \times p \times q},
$$

where $N$ is the population size, $p=1-q$ represents the yes/no categories, $z_{\alpha / 2}$ is CDF of normal distribution and finally $\varepsilon=0.07$ is the error term. Since we have $p=0.5, z_{\alpha / 2}=1.96$ and $N=26550$, the number of sample size is calculated as $n=195$. Table 1 shows details of the educational backgrounds of the people who participated in our survey.

\section{Table 1}

Educational background of the participants

\begin{tabular}{lllllll}
\hline Years of Education & $<12$ & 12 & 14 & 16 & 18 & Total \\
\hline Numbers & 546 & 3774 & 8643 & 11142 & 2445 & 26550 \\
Sample size & 4 & 26 & 59 & 81 & 16 & \\
\hline
\end{tabular}

In terms of participants' age, 23\% of the participants were 20 to 30 years old, $36 \%$ were 31 to 40 years old, $28 \%$ were 41 to 50 years old and 13\% were older than 50 years. In terms of gender, $44 \%$ of the participants were female and the remaining $56 \%$ were male. 
We have used questionnaire and interview experts to collect the necessary information. To design our questionnaire, we have interviewed with some university professrs as well as education expertises in province of Kermanshah, Iran. The final questionnaire consists of two parts, the first part asks for general information and the second part looks for managerial barriers in Likert scale. The propose model of this paper uses Freedman test to test the hypothesis and rank the components of the hyposis. According to Freedman test, we examine whether there is meaningful difference among $k$ different groups. The test uses Chi-Square to learn whether there is statistical difference among $\mathrm{k}$ groups or not. Table 2 shows details of the hypothesis and attributes.

\section{Table 2}

Main hypothesis and its attributes on management barriers on suggestions system

\begin{tabular}{|c|c|}
\hline & Attributes \\
\hline \multirow{7}{*}{$\begin{array}{l}\text { Lack of accepting any risk on behalf } \\
\text { of management team, conflict of } \\
\text { interest in management style, lack } \\
\text { of belief on suggestions system in } \\
\text { an organization are important } \\
\text { barriers of executing suggestions } \\
\text { system in an organization. }\end{array}$} & 1. Lack of management's belief to suggestions system \\
\hline & 2. Lack of management's support to suggestions system \\
\hline & 3. Weakness in education for suggestions system \\
\hline & $\begin{array}{l}\text { 4. Fear in management disruption becuase of having } \\
\text { suggestions system }\end{array}$ \\
\hline & $\begin{array}{l}\text { 5. Weakness in management position becuase of accepting } \\
\text { suggestions system }\end{array}$ \\
\hline & 6. Lack of accepting risk among management team \\
\hline & $\begin{array}{l}\text { 7. Existing conflict between management style and } \\
\text { suggestions system }\end{array}$ \\
\hline
\end{tabular}

\section{The results}

Table 3 shows the results of the survey in terms of frequency and percentage. We have performed tstudent test where the degree of freedom is 185 and the level of significance is five percent and it yielded $\mathrm{t}$-student $=4.3478$, which implies that the $\mathrm{t}$-student is statistically meaninful and we can confirm the main hypothesis.

\section{Table 3}

The results of the survey in terms of frequency and percentage

\begin{tabular}{lccccccccccc}
\hline & \multicolumn{2}{c}{ Completely } & \multicolumn{2}{c}{ Agree } & \multicolumn{3}{c}{ No-comment } & \multicolumn{3}{c}{ Disagree } & \multicolumn{3}{c}{ Completely disagree } \\
\cline { 2 - 11 } Attribute & areq. & $\%$ & Freq. & $\%$ & Freq. & $\%$ & Freq. & $\%$ & Freq. & $\%$ & Mean \\
\hline 1 & 14 & 7.5 & 52 & 27.9 & 36 & 19.4 & 60 & 32.3 & 23 & 12.4 & 3.17 \\
2 & 9 & 4.8 & 67 & 36 & 42 & 22.6 & 44 & 23.7 & 24 & 12.9 & 3.04 \\
3 & 11 & 5.9 & 28 & 15 & 41 & 22 & 72 & 38.7 & 34 & 18.3 & 3.58 \\
4 & 24 & 12.9 & 66 & 35.5 & 33 & 17.7 & 41 & 22 & 22 & 11.8 & 2.81 \\
5 & 22 & 11.8 & 46 & 24.7 & 36 & 19.3 & 54 & 29 & 28 & 15 & 3.13 \\
6 & 11 & 5.9 & 56 & 30.1 & 53 & 28.5 & 37 & 19.9 & 29 & 15.6 & 3.11 \\
7 & 16 & 8.6 & 64 & 34.4 & 49 & 26.3 & 43 & 23.1 & 14 & 7.5 & 2.84 \\
\hline
\end{tabular}

The implementation of Freedman test in our survey for the effects of suggession systems are summarized in Table 4. The results of Chi-square has rejected the null hypothesis and we can condfirm that lack of accepting any risk on behalf of management team, conflict of interest in management style, lack of belief on suggestions system in an organization are important barriers of executing suggestions system in an organization. In terms of Freedman test, lack of accepting risk among management team comes as the first priority, which means management team are not looking to jeopardize their position for taking any risk by accepting people's suggestions. 


\section{Table 4}

Main hypothesis and its attributes on management barriers on suggestions system

Hypothesis

Lack of accepting any risk on behalf of management team, conflict of interest in management style, lack of belief on suggestions system in an organization are important barriers of executing suggestions system in an organization.
Attributes

1. Lack of accepting risk among management team

2. Existing conflict between management style and suggestions system

3. Lack of management's belief to suggestions system

4. Weakness in education for suggestions system

5. Fear in management disruption becuase of having suggestions system

6. Lack of management's support to suggestions system

7.Weakness in management position because of accepting suggestions system

The survey also indicates that there is a conflict of interest between management style and suggestions system. This means managements follow conservative thems, which prevent them to accept any feedback from people. It is always important that management team believes to what they offered through feedback system and when management team do not believe to such idea, it is getting hard to estabish feedback system. The other important factor is the weakness in educational system, which prevents management teams to implement such system. In many cases, management teams believe there would be disruption in management style when a feedback system is established. One way to overcome to such barrier is to negotiate the advantage of having feedback system. Lack of management team's support is another important reason for not having suggestion system and finally some managers think their position will be weaken when suggestion system is executed in the system. In summary, Freedman test results have confirmed all seven hypotheses.

\section{Conclusion}

In this paper, we have presented an empirical investigation among managers who worked for education system in city of Kermanshah, Iran. The proposed study has designed and distributed a questionnaire among people and the primary purpose of this survey was to learn whether lack of accepting any risk on behalf of management team, conflict of interest in management style, lack of belief on suggestions system in an organization are important barriers of executing suggestions system in an organization or not. The results of Freedman test confirmed all components of the hypothesis. As a result, lack of accepting risk among management team is number one barrier in having suggestion system followed by existing conflict between management style and suggestions system and lack of management's belief to suggestions system, weakness in education for suggestions system and fear in management disruption because of having suggestions system. The other barriers coming in the last priority in terms of their relative importance include lack of management's support to suggestions system and weakness in management position becuse of accepting suggestions system.

\section{Aknowledgment}

The authors would like to thank the annonymous referees for their comments on earlier version of this paper.

\section{References}

Ahangari, S., \& Amirzadeh, S. (2011). Exploring the Teachers' Use of Spoken Corrective Feedback in Teaching Iranian EFL Learners at Different Levels of Proficiency. Procedia - Social and Behavioral Sciences, 29, 1859-1868. 
Anderson, C.R. (2004). Management: Skills, Function, and Organization Performance, $2^{\text {nd }}$ ed., Boston: Allyn and Ban Com.

Atwater, L.E., \& Brett, J.F. (2005). Antecedents and consequences of reactions to developmental $360^{\circ}$ feedback. Journal of Vocational Behavior, 66(3), 532-548.

Gao, L., Janssen, O., \& Shi, K. (2011). Leader trust and employee voice: The moderating role of empowering leader behaviors. The Leadership Quarterly, 22(4), 787-798.

Heresy, P. \& Blanchard, K. (2001). Management of organization. Behavior: Utilizing Human Resource. New York, Prentice - Hall International Edition, Fifth Edition.

Imai, M.(2002). Kaizen: The Key to Japan's Competitive Success. Random House business division, New York.

Jun, M., Cai, S., \& Shin, H. (2006). TQM practice in maquiladora: Antecedents of employee satisfaction and loyalty. Journal of Operations Management, 24(6), 791-812.

Milner, E., Kinnell, M. \& Usherwood, B. (1995). Employee Suggestion Schemes: a management tool for the 1990s? Library Management, 16(3), 3-8.

Pirayesh, R., Niazi, R., \& Ahmadkhani, A. (2012). Investigating the effective factors on management internal controls applying. Management Science Letters, 2(4), 1203-1208.

Recht, R., \& Wilderom, C. (1998). Kaizen and culture: on the transferability of Japanese suggestion systems. International Business Review, 7(1), 7-22.

Vakil Alroaia, Y., \& Najafi, Z. (2012). Performance measurement of employee using an integrated $360^{\circ}$ feedback system and AHP method: A case study of municipality. Management Science Letters, 2(5), 1655-1660.

Wood, J., Collins, J., Burnside, E.S., Albanese, M.A., Propeck, P.A., Kelcz, F., Spilde, J.M., \& Schmaltz, L.M. (2004). Patient, faculty, and self-assessment of radiology resident performance:: A 360-degree method of measuring professionalism and interpersonal/communication skills. Academic Radiology, 11(8), 931-939.

Yi, Y., Nataraajan, R., Gong, T. (2011). Customer participation and citizenship behavioral influences on employee performance, satisfaction, commitment, and turnover intention. Journal of Business Research, 64(1), 87-95 